\title{
TRAINING OF SOCIAL WORKERS SPECIALIZING AT WORK WITH “AT RISK" CHILDREN IN THE USA, GREAT BRITAIN AND UKRAINE: COMPARATIVE ANALYSIS
}

\begin{abstract}
The complicated social-economic situation worldwide is characterized by the social tension. Thus, it actualizes the training of social workers for the professional activity, raising the requirements for their professional competence. The problem of sociallegal protection and support of "at risk" children as well the issue of professional training of social workers for the work with "at risk" children has become the aim of our study. The empirical (observation, interviews with scientists and practical social workers which made it possible to analyze the foreign experience of social workers training) and theoretical (analysis of pedagogical sources on the study to systematize and generalize the available data, to determine the nature of basic concepts of the study, to identify the current state of problem under consideration; comparative analysis to identify specific features of social workers training in higher educational institutions of the USA, Great Britain and Ukraine) methods have been used.

This article considers particular issues of social workers training for the work with "atrisk" children, namely: interdisciplinary character of training; the optimal combination of theoretical and practical training; the widespread use of interactive teaching methods, potential of self-study, individual, scientific and research work of students; focus on field practice; curriculum aimed at training of social workers for the work with children "at risk"; partnership with social institutions and potential employers. The common features of American, British and Ukrainian systems of social workers training for the work with children "at risk" are the following: the taught direct work with children and families; focusing on human capabilities and resources; choosing the correct approach to children; collaboration with other social services; taught process of assessment, planning, implementation of practice tasks, monitoring etc.
\end{abstract}

Key words: the structure, content and organization of training; social workers; children «at risk»; the USA; Great Britain; Ukraine.

(статтю подано мовою оригіналу)

Social work is a unique profession that requires: in depth professional knowledge, abilities and skills; possession of professional and personal qualities; a high level of formation of psychological readiness for the performing of professional activities. A social worker is to understand not only the symptoms but also the causes of problems and is to be able to find ways to overcome them. Equally important is the properly organized and coordinated professional training. The problem of social-legal protection and support of «at risk" children as well the issue of professional training of social workers for the work with «at risk" children becomes rather topical as social, economic and political crisis of modern society has common features in different countries of the world. This problem has not become the subject of special educational research, thus is the purpose of our study. The empirical (observation, interviews with scientists and practical social workers which made it possible to analyze the foreign experience of social workers training) and theoretical (analysis of pedagogical sources on the study to systematize and generalize the available data, to determine the nature of basic concepts of the study, to identify the current state of problem under consideration; comparative analysis to identify specific features of social workers training in higher educational institutions of the USA, Great Britain and Ukraine) methods have been used.

Despite the fact that the American and British systems of social work organization have a long history, and the process of social work formation as a science and practice as well as the formation of the system of social workers training in Ukraine started together with the processes of its sovereignty formation, we find it possible to carry out their comparative analysis. Researchers define the following main problems of today's social work development in Ukraine: the lack of legal framework that would regulate the social work field; the absence of a unified concept of professional social workers training; the lack of full range of social services standards; the weak orientation of training on applied character of future professional activity and further employment of graduates; mostly theory-based learning process etc. [7].

The common features of social workers training in the USA and Great Britain are: the multi-level system of training; high quality of training programmes; focus on field practice; supervision over the training. The differences primarily relate to organizational forms and methods of educational process. Ukraine is also characterized by the multilevel system of social workers professional training, but the content of training programmes for master's and $\mathrm{PhD}$ level students has not yet been clearly developed.

The comparative analysis of social workers training in the USA and Great Britain indicates that the humanist-oriented approach to learning is leading here and it appeals to the individually oriented and differentiated learning. It should be emphasized that the American and British higher education in the training of social workers uses a variety of forms, methods and technologies: the technology of problem-based learning; the technology of group learning; the learning technology as research; the personality-oriented technology; the technology of interactive learning and others. Also educational games, reflexive games, didactic games and simulation games are actively used in social workers training. Much attention is paid to extracurricular work (individual and self-study work) and the research work of students. In Ukraine, there is the tendency to universal curricu- 
lum, frontal communication, standard assessment of knowledge and skills, lecture form of information transfer from a teacher to a student.

According to the conducted research and statistics, in order to get the social work bachelor's degree students need to undergo training programme (in the American college or school of social work accredited by the Council of Social Work Education in the USA [4]; in the British college or university accredited by the Care Council for Wales / Northern Ireland Social Care Council / Scottish Social Services Council / Health and Care Professions Council in England [2]. In these countries having received the social work bachelor degree graduates can start their career as general social workers or continue training in magistracy.

Master programmes are of practice oriented nature and take into account the scope of professional activity of future specialists. In the USA 1st year master programmes students undergo general training with its aim to master the theory and practice of social work. 2nd year master-students specialize and improve the level of practical professional training. The distinctive feature of master programmes is that they contain a basis component and specialization around the field of practice, problem sphere, methods or principles of influence or a combination of any of the above aspects. This is called "dual concentration" of specialized knowledge and practical skills in one or more fields or methods of social work - defined practical method of learning and branch of practice. The choice of these two elements affect courses selection and choice of location for practical training the students will attend. Branch of practical training includes selected area of activity, that is its specificity, procedures, practices (such as children and young people in families and society, the elderly in the family and society, health care, mental health protection and community social system) [1].

The comparative analysis of social workers training for the work with "at risk" children in the USA, Great Britain and Ukraine shows that the content of training is reflected in the curriculum.

In the USA social work with "at risk" children is the second popular "concentration" in social workers training [3], whom accredited programmes offer among the others the following courses to study: "Child Protection", "Child Psychology", "Welfare Policy: Children, Youth and Families", "School Social Work", "Child Development", "Models of Intervention in Cases of Child Abuse and Child Neglect", "Asocial Behavior in Childhood: Theory and Practice", "Direct Social Work Practice with Children and Families", "Child Abuse and Family Violence", "Mental Health of Children", "Social Work with Children", "Adoption: the Prospects for Social Work", "Foster Families".

In Great Britain the importance of studying of the following courses in the process of social workers training for the work with "at risk" children has been emphasized: "Communication with Children and Young People", "Child Development (psychological, mental and physical)", "Evaluation of Parents", "Planning and Process of Care (the care for children and youth people, foster care and adoption, post-institutional care, etc.)", "Working with Children with Special Needs and their Families", "Legal Aspects of Work with Juvenile Offenders", "Child Abuse” [1].

The course "Social Work with Children and Families" and practice in social agencies are considered in educational institutions of the USA and Great Britain to be the main components of social workers training for the work with "at risk" children. Within the course the following topics are considered: historical context of child's welfare; theories to prevent the children impoverishment and protection provision; in / outside family care for children; understanding social work values in the work with children, changes in legislation; network of welfare services for children; status of a child, of a juvenile offender in the social work practice etc.

Uzhhorod National University was the first higher educational institution of Ukraine, which initiated the training of social work specialists. Teaching staff of the Sociology and Social Work Department emphasizes the importance of learning of the following (compulsory) group of courses in the training of social workers-bachelors for the work with "at risk" children: "Social Work with Different Groups of Clients", "Social Work with Children and Youth", "Family Social Work", "Social Work with People Inclined to Deviant Behaviour", "Social Work with Violence Victims", "Social Work with People with Special Needs", "Social Work with Disadapted Children".

Within each course particular aspects of social work with "at risk" children are addressed, but the course "Social Work with Different Groups of Clients" is the core one. Students are to know: the essence of technologies of social work with "at risk" children; possibilities of theoretical and practical models of social work with "at risk" children; the specificity of use of sociological, psychological, educational, legal and other methods in the practice of social work with "at risk" children. Students are to be able to: substantiate the efficiency (inefficiency) of various forms and methods of practical social work with "at risk" children. The following themes are considered: interpretation of concepts of "asocial", "deviant", "delinquent" behaviour of children; social preconditions, forms (displays) of asocial behaviour; organizational forms and technologies of social work with children with deviant behaviour; the structure of the bodies, offices and institutions for children with asocial behaviour; the aim and tasks of preventive work with "at risk" children and teenagers; orphanage as a social problem; state system of maintenance, upbringing and education of orphans and children deprived of parental care; the problem of development of institutional care of orphans and children deprived of parental care; trends towards the development of family-based child care as a part of de-institutionalization; family-type homes, foster families; the phenomenon of violence and child abuse; organizations working on behalf of children on issues of child abuse; the aim and tasks of social and educational rehabilitation of "at risk" children.

The comparative analysis of universities curricula and programmes indicates that the principal difference between models of social workers training is the orientation of the content of training programmes in the USA 
and Great Britain on the problem prevention, preventive care, social and legal protection of children, and in Ukraine - on therapeutic assistance, correction of deviations [6].

The common feature of American, British and Ukrainian training systems for the work with "at risk" children is that students are taught: direct work with children and families; focusing on human capabilities and its resources; the correct approach to children; collaboration with other social services etc.; the process of assessment (correct assessment after the collection of information); planning (defining the opportunities and coordination role, tasks and priorities); monitoring etc. Students analyze policies and services designed to address the problems of children and their families (child abuse, child neglect, juvenile justice, homelessness, foster care, adoption, the impact of discrimination), gain knowledge to develop strategies, methods and skills for the effective problem solving.

The difference is that, in the USA the emphasis is put on clinical application of these concepts in the evaluation of social services for children and families; in Great Britain it is put on researching the norms in child's behaviour, its deviations in psycho-social context and consequences of the practice; in Ukraine - on the tasks, functions and principles of social rehabilitation of "at risk" children.

Another distinctive feature in social workers training for the work with "at risk" children is the taking into account of employers standards who are involved in the development of key demands to the training of social workers for the child care and protection in the USA and Great Britain. Employers encourage social workers to improve their skills and capacity to conduct research and perform good practice under their supervision. This approach encourages institutions of these countries to develop and implement a large number of short-term aimdirected programmes - courses for professionals who specialize in work with "at risk" children - often based on distance learning and online education allowing to combine work with study.

It should be noted that in the USA and Great Britain the practical experience (gained in specialized institutions) and/or volunteer practice with "at risk" children is the necessary precondition for the admission to master degree programmes that specialize in training for the work with this category of clients. There are also age restrictions for the course admission. In these countries the average age of social work students is 25-30 years. Obviously, this feature can be explained by the specificity of profession that requires certain maturity, experience and the desire for dedication.

The curriculum for bachelors and masters training combine theoretical and practical professional training of social workers for the work with "at risk" children are built on the idea of active and participatory learning. Field practice is an obligatory component of educational and professional programmes to obtain the qualification, which is aimed to develop the students' skills and abilities. The aim of practical training of future social workers is to form professional skills and personal qualities as specialists, to master the most important types of professional activity [5].

The main difference between the models of practice for social workers in the USA and Great Britain is the number of hours allocated for practice, the number of places for practice and organizational structure of practice. e.g. the biggest number of hours allocated for practical training of bachelors is given in Great Britain - 1200, during which a student is expected to receive educational experience in at least three areas of practice; the smallest - in the USA - 400 hours in one placement. The most comprehensive is the American model whith participantion of three people from the university and one person from student placement in practice organization. The most clear organizational structure has practice in Great Britain with one person from university and one person from student placement involved. Regular meetings and discussions are also held between these key figures, which promotes active student support and integrates knowledge into practice. In terms of Ukrainian university education, the practical training of future social workers is provided primarily through their involvement in volunteer activities and through different types of practices. Bachelors pass theoretical study ( 240 credits) and practice ( 24 credits), masters respectively -60 credits and 6 credits. Such a small percentage of credits allocated for practice cannot promote proper training of social workers, because during practice each student applies theoretical social work knowledge in practical situations of professional activity, directly absorbs the ethics and values of social work, generates professionally important qualities and works out own style of professional activity.

Field practice for social workers who specialize on the work with "at risk" children in the USA and Great Britain is obligatory and is organized in social agencies where children are the clients. It should be noted that there is no universal standard for terms of organization and practice passing in these countries, except the recommended number of practice hours (up to 50\% of the whole amount of credits at both social work bachelor and master levels) allocated for each year of training. Educational institutions decide themselves or together with social agencies on curriculum, which is to reflect the institution mission, the aim of curriculum to meet the community needs [5].

Conclusions. The modern Ukrainian society is characterised by the following social problems: unemployment, the family crisis, large number of marginalized members of society, material hardships, drug addiction, alcoholism etc. Therefore, we find it quite possible to use the American and British idea to specialize master's programmes of social workers training on clients needs, "at risk" children in particular. The conducted study does not cover all aspects of theory and practice of training of future social workers for the work with "at risk" children. In fact, the education and training of social workers has still a lot of problems and cearful use of foreign experience enables us to solve at least some of them. Thus, the results of analysis of the national Ukrainian system and foreign experience indicate the need to improve the training of future social workers to the work with "at risk" children in Ukraine. 
Bibliography:

1. Bartosh O., Kozubovska I., Kozubovskyi R., Shandor F. Content of social workers' training for the work with children in the UK, the USA and Ukraine (Зміст підготовки соціальних працівників до роботи з дітьми у Великій Британії, США та Україні). Соціальна робота: виклики сьогодення. Збірник наукових праць та матеріали VIII Міжнародної науково-практичної конференції, 18-19 квітня 2019 року / за заг. ред. В. А. Поліщук, С. М. Калаур, Г. І. Слозанської. Тернопіль : ТНПУ ім. В. Гнатюка. 2019. С. 24-32.

2. Poliszczuk W., Horiszna N., Bartosz-Piczkar O., Pryszkiak O. Praca socjalna. Poland: Niepubliczna Placowka Ksztalcenia Ustawicznego Siemianowicki Osrodek Szkoleniowy: Siemianowice Slaskie, 2011. 273 s.

3. The Council on Social Work Education. Annual Statistics on Social Work Education in the USA. USA: Council on Social Work Education, 2016. 38 p.

4. The Council of Social Work Education. Accreditation. Current Number of Social Work Programs. USA: Council on Social Work Education, 2021. URL: http://www.cswe.org/Accreditation.aspx (Last accessed: 28.03.2021).

5. Бартош О. П. Деякі аспекти професійної підготовки майбутніх соціальних працівників на засадах праксеологічного підходу у вищих навчальних закладах України. Науковий вісник Ужгородського університету. Серія: Педагогіка. Соціальна робота. 2014. Вип. 34. С. 14-21.

6. Загайко О. Загальне та відмінне у підготовці соціальних працівників у ВНЗ України та Великої Британії. Ефективний настрій сучасних наук : матеріали IV науково-практичної конференції, Прага, Чехія, 15 квітня 2008 р. Прага: Education and Science s. r. o., 2008. C. 20-22.

7. Захарчук К. Особливості фахової підготовки соціальних працівників у Сполучених штатах Америки та проблеми української освітньої практики. Збірник наукових пращьь Хмельницького інституту соиіальних технологій Університету «Україна». 2010. № 2. С. 91-94.

\section{References:}

1. Bartosh, O., Kozubovska, I., Kozubovskyi, R., \& Shandor, F. (2019). Content of social workers' training for the work with children in the UK, the USA and Ukraine. In V. Polishchuk, S. Kalaur, G. Slozanska (Eds.). Sotsial'na robota: vyklyky s'ohodennya [Social Work: todays' challenges] - Proceedings of VIII International scientific-practical conference (pp. 24-32). V. Hnatyuk Ternopil National Pedagogical University.

2. Poliszczuk, W., Horiszna, N., Bartosz-Piczkar, O, \& Pryszkiak, O. (2011). Praca socjalna [Social Work]. Niepubliczna Placowka Ksztalcenia Ustawicznego Siemianowicki Osrodek Szkoleniowy: Siemianowice Slaskie. [in Polish].

3. The Council on Social Work Education. (2016). Annual Statistics on Social Work Education in the United States. Council on Social Work Education.

4. The Council of Social Work Education. Accreditation. (2021). Current Number of Social Work Programs. URL: http://www.cswe.org/Accreditation.aspx.

5. Bartosh, O. (2014). Deyaki aspekty profesiynoyi pidhotovky maybutnikh sotsial'nykh pratsivnykiv na zasadakh prakseolohichnoho pidkhodu u vyshchykh navchal'nykh zakladakh Ukrayiny [To the issue of professional training of future social workers on the basis of praxeological approach in higher education institutions of Ukraine]. Scientific Herald of Uzhhorod University. Series: Pedagogy. Social Work, 34, 14-21. [in Ukrainian].

6. Zahaiko, O. (2008). Zahalne ta vidminne u pidhotovtsi sotsialnykh pratsivnykiv u VNZ Ukrainy ta Velykoi Brytanii [General and special aspects in training of social workers in the universities of Ukraine and Great Britain]. Efektivni nastroje modernich ved Proceedings of IV International scientific-practical conference (pp. 20-22). Education and Science s. r. O. [in Ukrainian].

7. Zakharchuk, K. (2010). Osoblyvosti fakhovoi pidhotovky sotsialnykh pratsivnykiv u Spoluchenykh Shtatakh Ameryky ta problemy ukrainskoi osvitnoi praktyky [The specificity of professional training of social workers in the USA and the problems of Ukrainian educational practice]. Zbirnyk naukovykh prats Khmelnytskoho instytutu sotsialnykh tekhnolohii Universytetu "Ukraina", 2, 91-94. [in Ukrainian].

Бартош О. П. Підготовка соціальних працівників до роботи з дітьми групи “ризику” у США, Великій Британії та Украӥні: порівняльний аналіз

Складне соціально-економічне становище у всьому світі характеризується соціальною напруженістю, що актуалізує підготовку соиіальних працівників до професійної діяльності, підвищуючи вимоги до їхньої професійної компетентності. Проблема соціально-правового захисту та підтримки дітей “групи ризику”, а також питання професійної підготовки соиіальних працівників до роботи з дітьми “групи ризику” є метою нашого дослідження. У дослідженні використано такі методи: емпіричний (спостереження, співбесіди з науковиями та практичними соціальними працівниками), щзо дав змогу проаналізувати зарубіжний досвід підготовки соціальних працівників; теоретичний (аналіз наукових джерел для систематизаиї та узагальнення наявних даних, для визначення природи основних понять дослідження, для виявлення сучасного стану проблеми, щуо розглядається); порівняльний аналіз для виявлення спещифічних особливостей підготовки соиіальних прачівників у вищих навчальних закладах США, Великої Британії та України.

У иій статті розглядаються окремі питання підготовки сочіальних прачівників для роботи з дітьми, щзо перебувають у групі ризику, а саме: міждисциплінарний характер навчання; оптимальне поєднання теоретичної та практичної підготовки; широке використання інтерактивних методів навчання, потенціалу самонавчання, індивідуальної, наукової та дослідницької роботи студентів; наголос на практичній підготовці; навчальна програма, спрямована на підготовку соиіальних працівників для роботи з дітьми “групи ризику”; партнерство із сочіальними установами та потенційними роботодавиями. Спільними рисами американської, британської та украӥнської систем підготовки соціальних працівників для роботи з дітьми “групі ризику” с такі: навчання безпосередній роботі з дітьми та сім'ями; зосередження уваги на людських можливостях та ресурсах; вибір правильного підходу до дітей; співпраия з іншими соціальними службами; навчання оцінювання, планування, моніторингу тошо.

Ключові слова: структура, зміст та організація навчання, соціальні прачівники, діти “групи ризику”, США, Велика Британія, Україна. 